\title{
UJI IRITASI FORMULASI SEDIAAN KRIM EKSTRAK BAWANG DAYAK (Eleutherine bulbosa (Mill.) Urb) PADA KELINCI ALBINO PUTIH
}

\author{
Syahrida Dian Ardhany ${ }^{1}$, Rizky Ramadhani Effendie ${ }^{1}$, Susi Novaryatiin ${ }^{1}$ \\ ${ }^{1}$ Program Studi DIII Farmasi, Fakultas IImu Kesehatan, Universitas Muhammadiyah \\ Palangka Raya, Palangka Raya, Kalimantan Tengah
}

e-mail : chass501@gmail.com

\begin{abstract}
ABSTRAK
Berdasarkan penelitian sebelumnyaekstrak etanol umbi bawang dayak (Eleutherine bulbosa (Mill.) Urb) telah diuji mampu menghambat pertumbuhan beberapa bakteri penyebab jerawat, sehingga dilakukan pembuatan sediaan krim anti acne untuk mempermudah pemakaian. Penelitian ini bertujuan untuk mengetahui aktifitas iritasi primer krim ekstrak etanol bawang dayak menggunakan metode uji tempel (patch test). Hasil penelitian menunjukkan bahwa indeks iritasi primer kelompok kontrol $(0.625<2)$, P1 sebanyak $1 \mathrm{~g}$ krim $(0.75<2)$, P2 sebanyak $0.5 \mathrm{~g}$ krim $(0<2)$ dan P3 sebanyak $0.25 \mathrm{~g}$ krim $(0<2)$ termasuk dalam kategori iritasi tidak tampak, sehingga dapat disimpulkan bahwa krim ekstrak etanol bawang dayak tidak mengiritasi pada hewan uji secara topikal.
\end{abstract}

Kata Kunci : Bawang Dayak, Eleutherine bulbosa, Krim, Patch test, Uji Iritasi

\begin{abstract}
Based on research before, ethanolic extract of bawang dayak (Eleutherine bulbosa (Mill.) Urb) has been tested can inhibit growth of acne-causing bacteria, thereforemade a anti-acne cream for easy used. Thi study aims to know primary irritation activity of bawang dayak using patch test method. The results showed that the primary irritation index of control group $(0.625<2)$, P1 was $1 \mathrm{~g}$ of cream $(0.75<2)$, P2 was $0.5 \mathrm{~g}$ of cream $(0<2)$ and P3 was $0.25 \mathrm{~g}$ of cream $(0<2)$ in category of invisible irritation, so it can be concluded that the cream of ethanolic extract of bawang dayak topically does not irritate animals.
\end{abstract}

Keywords: Bawang Dayak, Cream, Eleutherine bulbosa, Patch test, Irritation test

\section{PENDAHULUAN}

Acne vulgaris (Jerawat) merupakan salah satu penyakit kulit yang dapat mengganggu penampilan dan mengurangi rasa percaya diri meskipun tidak berdampak fatal [1,2].Bawang dayak merupakan tanaman khas Kalimantan Tengah. Tanaman ini sudah turun temurun dipergunakan masyarakat dayak sebagai tanaman obat. Senyawa bioaktif seperti fenol, flavonoid, tanin, glikosida, steroid, alkaloid terdapat pada bawang dayak[3].Berdasarkan penelitian sebelumnya ekstrak bawang dayak mampu menghambat beberapa bakteri penyebab jerawat seperti Staphylococcus 
aureus, Staphylococcus epidermidis dan Propionibacterium

acnes[4,5,6].kemungkinan karena terdapatnya flavonoid yang merupakan senyawa fenolik alam yang berpotensial sebagai antioksidan juga sebagai antibakteri [7].Selain itu menurut Padhi dan Panda aktifitas antibakteri dari eleutheribe bulbosa kemungkinan karena adanya kandungan senyawa aromatik dan glikosida, seperti eleutherinone, eleutherine, isoeleutherine, eleutherol, $(R)$ 4-hydroxyeleutherine, eleuthone, isoeleuthoside $C$ dan eleutherinol 8-O- $\beta D$ glucoside [8].

Dalam dunia farmasi, untuk meningkatkan efisiensi penggunaan obat tradisional dapat dilakukan pembuatan sediaan farmasi yang bertujuan memudahkan cara pakai obat tradisional tersebut. Salah satu sediaannya adalah dalam bentuk krim (Cremores).Krim merupakan sediaan semi padat berupa emulsi minyak dalam air (m/a) ataupun air dalam minyak $(a / m)$. Basis krim dapat menyebabkan efek samping pada kulit, seperti iritasi primer, reaksi sensitasi, fotoalergi dan fototoksisitas, efek samping tersebut dapat berasal dari zat aktif maupun basis krim, evaluasi keamanan kosmetik salah satunya uji iritasi harus dilakukan sebelum pemakaian pada manusia untuk mencegah reaksi hipersensitifitas [9].Pentingnya mengetahui apakah sediaan krim yang dibuat mempunyai potensi untuk mengiritasi dapat dilakukan dengan uji iritasi primer kualitatif menggunakan hewan percobaan [10].Penelitian ini bertujuan untuk mengetahui nilai indeks iritasi primer pada krim yang mengandung ekstrak bawang dayak.

\section{METODOLOGI}

\section{Rancangan Penelitian}

Penelitian ini bersifat eksperimental yaitu suatu penelitian dengan melakukan kegiatan percobaan yang bertujuan untuk mengetahui gejala atau pengaruh yang timbul sebagai akibat dari perlakuan tertentu. Metode yang digunakan pada penelitian ini yaitu metode uji tempel (patch test), uji ini merupakan uji iritasi primer yang diukur dengan suatu tekhnik uji tempel pada kulit yang utuh dan kulit yang hampir luka pada kelinci yang rambutnya telah dicukur [11].

\section{Alat dan Bahan}

Alat yang digunakan yaitu perkolator, alatalat gelas, penggaris, spidol, gunting, silet, alat cukur, kain kasa, plester luka, timbangan dan kamera, sedangkan bahan yang digunakan yaitu umbi bawang dayak yang diperoleh dari petani di Sei Gohong, Tangkiling Kalimantan Tengah, etanol 96\%, aquadest, asam stearat, TEA, paraffin liquid, adeps lanae, nipagin dan ol.Rosae 
Tabel 1. Formulasi Sediaan Krim Ekstrak Etanol Umbi Bawang (Eleutherine bulbosa (Mill.)

Urb)

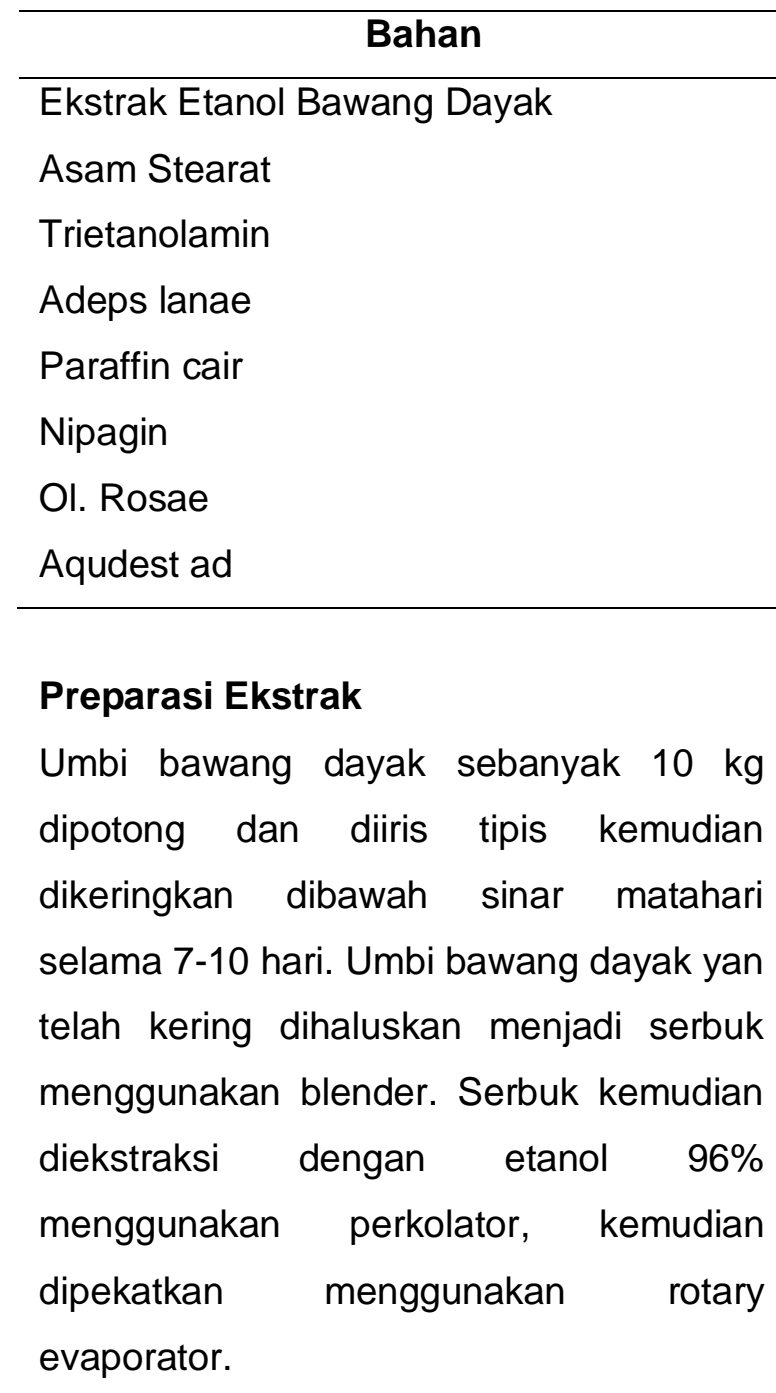

\section{Pembuatan Krim}

Seluruh bahan-bahan yang digunakan dalam pembuatan krim (Tabel 1) masingmasing ditimbang, kemudian dipisahkan bahan-bahan fase lemak (asam stearat, adeps lanae, paraffin liquid) dan fase air (TEA, nipagin dan aquadest).Fase minyak dipanaskan hingga suhu $55^{\circ} \mathrm{C}$ sampai seluruh bahan melebur. Masukkan fase minyak yang telah dilebur diatas waterbathke dalam mortir, gerus cepat kemudian masukkan sedikit demi sedikit fase air, gerus sampai homogen hingga

terbentuk basis krim, terakhir masukkan ekstrak bawang dayak sedikit demi sedikit digerus hingga homogen dan tambahkan ol.rosae aduk sampai homogen. Krim dimasukkan ke dalam wadah dan diberi label.

\section{Uji Iritasi Primer Kualitatif}

Hewan uji yang digunakan yaitu kelinci putih betina sebanyak 4 ekor, 2 ekor untuk kelompok insisi dan sisanya untuk kelompok non insisi.Setiap kelinci dicukur bagian punggungnya dan dibagi sebanyak empat buah dengan luas permukaan64 $\mathrm{cm}^{2}(8 \mathrm{~cm} \times 8 \mathrm{~cm})$. Setiap kelinci yang telah dicukur punggungnyadiaplikasikan kontrol negatif (vaselin putih) sebanyak 1 g, krim ekstrak etanol bawang dayak $0.25 \mathrm{~g}, 0.5 \mathrm{~g}$ dan $1 \mathrm{~g}$, kemudian ditutup dengan menggunakan kassa. Pengamatan eritema dan edema dilakukan pada jam ke-24 dan 72 jam setelah pemejanan.Setiap keadaan kulit diberi nilai sesuai metode skoring sebagai berikut:

1. Eritema 
a. Tanpa eritema $=0$

b. Eritema sangat sedikit (hampir tidak tampak) $=1$

c. Eritema berbatas jelas $=2$

d. Eritema moderat sampai berat $=3$

e. Eritema berat, sedikit kerak (luka dalam) $=4$

2. Edema

a. Tanpa edema $=0$

b. Edema sangat sedikit (hampir tidak tampak) $=1$

c. Edema berbatas jelas $=2$

d. Edema moderat (tepi naik kira-kira $1 \mathrm{~mm})=3$

e. Edema berat (naik lebih dari $1 \mathrm{~mm}$ dan meluas keluar daerah paparan) $=4$

Indeks iritasi primer:

a. $<2=$ Iritasi tidak tampak

b. $2-5=$ Iritasi moderat

c. $>6=$ Iritasi berat

\section{HASIL DAN PEMBAHASAN}

Ada beberapa faktor yang mempengaruhi efek kosmetika terhadap kulit, selain faktor iklim, manusia salah satu faktor yang paling penting adalah kosmetika itu sendiri. Kosmetika yang dibuat dengan bahan berkualitas rendah atau bahan berbahaya bagi kulit dan cara pengolahannya yang kurang baik, dapat menimbulkan reaksi negatif atau kerusakan kulit seperti alergi dan iritasi [12].Oleh sebab itu, penting kiranya dilakukan uji iritasi primer pada hewan coba sebelum produk diaplikasikan atau digunakan oleh masyarakat luas untuk menghindari efek samping yang tidak diinginkan.Pada penelitian ini sediaan kosmetika yang dibuat adalah krim dengan berbahan aktif ekstrak bawang dayak yang pada penelitian sebelumnya secara mikrobiologi bawang dayak dapat menghambat pertumbuhan beberapa bakteri penyebab jerawat.

Pembuatan ekstrak umbi dayak dilakukan dengan cara ekstraksi dingin menggunakan metode perkolasi dengan pelarut etanol 96\%, keuntungan metode perkolasi dapat menyari lebih sempurna dibandingkan metode maserasi karena menggunakan bantuan alat perkolator [13]. Pelarut etanol 96\% dipilih karena merupakan pelarut universal yang dapat melarutkan hampir semua senyawa metabolit sekunder yang terkandung dalam simplisia [14].Pada penelitian ini serbuk simplisia diekstraksi sebanyak $5300 \mathrm{~g}$ dan didapatkan ekstrak kental $315,6 \mathrm{~g}$ sehingga rendemen ekstrak umbi dayak adalah 5.95\%.Selanjutnya dilakukan pembuatan krim dengan bahan yang tertera pada Tabel 1. 
Tabel 2. Pengamatan Hewan Uji

\begin{tabular}{|c|c|c|c|c|c|c|c|c|c|}
\hline \multirow{3}{*}{$\begin{array}{c}\text { Hewan } \\
\text { Uji }\end{array}$} & \multirow{3}{*}{ Perlakuan } & \multicolumn{4}{|c|}{ Kelompok Insisi } & \multicolumn{4}{|c|}{ Kelompok Non Insisi } \\
\hline & & \multicolumn{2}{|c|}{24 jam } & \multicolumn{2}{|c|}{72 jam } & \multicolumn{2}{|c|}{24 jam } & \multicolumn{2}{|c|}{72 jam } \\
\hline & & ${ }^{\star}$ Eri & ${ }^{*}$ Ede & ${ }^{\star}$ Eri & ${ }^{*}$ Ede & ${ }^{*}$ Eri & ${ }^{*}$ Ede & ${ }^{*}$ Eri & ${ }^{*}$ Ede \\
\hline \multirow{4}{*}{ Kelinci 1} & Kontrol & 0 & 0 & 0 & 0 & 0 & 0 & 0 & 0 \\
\hline & P1 (1g) & 0 & 2 & 0 & 4 & 0 & 0 & 0 & 0 \\
\hline & P2 $(0.5 \mathrm{~g})$ & 0 & 0 & 0 & 0 & 0 & 0 & 0 & 0 \\
\hline & P3 (0.25g) & 0 & 0 & 0 & 0 & 0 & 0 & 0 & 0 \\
\hline \multirow{4}{*}{ Kelinci 2} & Kontrol & 0 & 2 & 0 & 3 & 0 & 0 & 0 & 0 \\
\hline & P1 (1g) & 0 & 0 & 0 & 0 & 0 & 0 & 0 & 0 \\
\hline & P2 $(0.5 \mathrm{~g})$ & 0 & 0 & 0 & 0 & 0 & 0 & 0 & 0 \\
\hline & P3 $(0.25 g)$ & 0 & 0 & 0 & 0 & 0 & 0 & 0 & 0 \\
\hline
\end{tabular}

Uji iritasi primer dilakukan dengan metode patch test(Uji tempel) menggunakan hewan uji kelinci albino betina.Hewan uji dibagi menjadi dua kelompok yaitu kelompok insisi (kulit lecet) dan kelompok non insisi (kulit normal) [15].Hasil pengamatan (Tabel 2) menunjukkan pada kelompok insisi terdapat sejumlah eritema dan edema pada kelompok kontrol (kelinci 2) dan perlakuan 1 (kelinci 1), sedangkan pada kelompok non insisi tidak terdapat eritema dan edema, namun apabila dihitung berdasarkan indeks iritasi primer seluruh kontrol dan perlakuan dapat dikategorikan iritasi tidak tampak $(<2)$ atau tidak mengiritasi (Tabel 3).Pada penelitian ini kelompok insisi (luka lecet) terdapat eritema dan edema kemungkinan besar bukan dikarenakan komposisi sediaan krim namun bisa jadi karena luka yang dibuat pada kelinci terlalu dalam, sehingga ini dapat menjadi salah satu kekurangan dalam proses penelitian.

Tabel 3.Skor eritema dan edema dan indeks iritasi primer

\begin{tabular}{|c|c|c|c|c|c|c|c|c|c|c|c|c|}
\hline \multirow{3}{*}{$\begin{array}{l}\text { Rata-Rata } \\
\text { Perlakuan } \\
\text { Hewan Uji }\end{array}$} & \multicolumn{4}{|c|}{ Kel . Insisi (A) } & \multirow{3}{*}{$\begin{array}{l}\text { Rata- } \\
\text { Rata } \\
\text { (A) }\end{array}$} & \multicolumn{4}{|c|}{ Kel . Non Insisi (B) } & \multirow{3}{*}{$\begin{array}{l}\text { Rata- } \\
\text { Rata } \\
\text { (B) }\end{array}$} & \multirow{3}{*}{$\begin{array}{c}\text { Indeks } \\
\text { iritasi } \\
\text { primer } \\
(A+B)\end{array}$} & \multirow{3}{*}{ Keterangan } \\
\hline & \multicolumn{2}{|c|}{24 jam } & \multicolumn{2}{|c|}{72 jam } & & \multicolumn{2}{|c|}{24 jam } & \multicolumn{2}{|c|}{72 jam } & & & \\
\hline & ${ }^{*}$ Eri & ${ }^{*}$ Ede & ${ }^{*}$ Eri & ${ }^{*}$ Ede & & ${ }^{\star}$ Eri & ${ }^{\star}$ Ede & ${ }^{\star}$ Eri & ${ }^{\star}$ Ede & & & \\
\hline Kontrol & 0 & 1 & 0 & 1.5 & 0,625 & 0 & 0 & 0 & 0 & 0 & 0,625 & $\begin{array}{c}\text { Iritasi tidak } \\
\text { tampak }\end{array}$ \\
\hline $\begin{array}{l}\text { Perlakuan } \\
1(1 \mathrm{~g})\end{array}$ & 0 & 1 & 0 & 2 & 0,75 & 0 & 0 & 0 & 0 & 0 & 0,75 & $\begin{array}{c}\text { Iritasi tidak } \\
\text { tampak }\end{array}$ \\
\hline $\begin{array}{l}\text { Perlakuan } \\
2(0,5 \mathrm{~g})\end{array}$ & 0 & 0 & 0 & 0 & 0 & 0 & 0 & 0 & 0 & 0 & 0 & $\begin{array}{c}\text { Iritasi tidak } \\
\text { tampak }\end{array}$ \\
\hline $\begin{array}{l}\text { Perlakuan } \\
3(0,25 \mathrm{~g})\end{array}$ & 0 & 0 & 0 & 0 & 0 & 0 & 0 & 0 & 0 & 0 & 0 & $\begin{array}{l}\text { Iritasi tidak } \\
\text { tampak }\end{array}$ \\
\hline
\end{tabular}




\section{KESIMPULAN}

Sediaan krim ekstrak etanol bawang dayak memiliki indeks iritasi primer yang termasuk dalam kategori iritasi tidak tampak atau tidak menimbulkaniritasi primer pada kulit kelinci secara topikal.

\section{DAFTAR PUSTAKA}

1. Umah $\mathrm{K}$ dan Herdanti O. 2017. Masker Madu Berpengaruh pada Penyembuhan Acne Vulgaris. Journals of Ners Community Vol. 08 No: $02 \mathrm{Hal}:$ 179-187

2. Saragih, D.F., Opod H., Pali C. 2016. Hubungan Tingkat Kepercayaan Diri dan Jerawat (Acne vulgaris) pada Siswa-Siswi Kelas XII di SMA Negeri 1 Manado. Jurnal e-Biomedik (eBm) Vol.4 No: 1

3. Mustika N. A. 2011. Kapasitas Antioksidan Bawang Dayak (Eleutherine palmifolia) dalam Bentuk Segar, Simplisia dan Keripik, pada Pelarut Nonpolar, Semipolar dan Polar. Skripsi. Fakultas Teknologi Pertanian Institut Pertanian Bogor. Bogor

4. Novaryatiin, S., Pratiwi, A.M., Ardhany, S.D. 2018. Uji Daya Hambat Ekstrak Etanol Bawang Dayak (Eleutherine bulbosa (Mill.) Urb.) terhadap Bakteri Staphylococcus epidermidis. Anterior Jurnal Vol. 18 Issue I Hal: 92-97

5. Novaryatiin, S. Ramli, A., Ardhany S.D. 2019. Uji Daya Hambat Ekstrak Etanol Bawang Dayak (Eleutherine bulbosa (Mill.) Urb.) terhadap Bakteri Staphylococcus aureus. Jurnal Surya Medika Vol. 4 No: 2 Hal: 51-59

6. Novaryatiin, S., Ardhany, S.D. 2019. The Antibacterial Activity of Bawang Dayak (Eleutherine bulbosa (Mill.) Urb). From
Central Kalimantan Against Acne-Causing Bacteria. Presented on $4^{\text {th }}$ International Conference on Pharmacy and Pharmaceutical Science (ICPPS 2019). Tokyo

7. Baharfar, R., Azimi R., Mohseni M. 2015. Antioxidant and Antibacterial Activity of Flavonoid-, Polyphenol- and Anthocyaninrich Ecxtracts from Thymus kotschyanus boiss \& hohen aerial parts. J Food Sci Technol 52 (10):6777-6783

8. Padhi, L., Panda, S.K.2015. Antibacterial Activity of Eleutherine bulbosa against multidrug-resistant bacteria. Journal of Acute Medicine Vol. 5 Issue 3: 53-61

9. Fatmawaty, A., Manggau M.A., Tayeb R., Al Adawiah R. 2016. Uji Iritasi Krim Hasil Fermentasi Bunga Rosella (Hibiscus sabdariffa L.) dengan Variasi Konsentrasi Emulgator Novemer pada Kulit Kelinci (Oryctalagus cuniculus). Journal of Pharmaceutical and Medicinal Sciences 1(2): $62-65$

10. Toding, L.G dan Zulkarnaian A.K. 2015. Optimasi Formula dan Uji Iritasi Primer Kualitatif pada Kelinci Putih Betina dengan Krim w/o Ekstrak Etanolik Buah Mahkota Dewa (Phaleria macrocarpa (Scheff.) Boerl.). Majalah Farmaseutik Vol. 11 No:2 Hal: 321-327

11. Lu, F.C. 1995. Toksikologi Dasar Asas, Organ Sasaran dan Penilaian Resiko. Edisi Kedua. UI-Press: Jakarta

12. Pangaribuan, L. 2017. Efek Samping Kosmetik dan Penanganannya bagi Kaum Perempuan. Jurnal Keluarga Sehat Sejahtera Vol. 5 (2): 20-28

13. Verawati, Nofiandi, D., Petmawati. 2017. Pengaruh Metode Ekstraksi terhadap Kadar Fenolat Total dan Aktivitas 
Antioksidan Daun Salam (Syzygium polyantum (Wight) Walp.). Jurnal Katalisator Vol. 2 No:2 Hal: 53-60

14. Arifianti, L., Oktarina R.D., Kusumawati I. 2014. Pengaruh Jenis Pelarut Pengekstraksi terhadap Kadar Sinensetin dalam Ekstrak Daun Orthosiphon stamineus Benth. E-Journal Planta Husada Vol. 2 (1) : 1-4

15. Rahman, A.G., Astuti, I.Y., Dhiani, B.A. 2013. Formulasi Lotion Ekstrak Rimpang Bangle (Zingiber purpureum Roxb) dengan Variasi Konsentrasi Trietanolamin sebagai Emulgator dan Uji Iritasinya. Pharmacy Vol. 10 No: 01 Hal: 41-54 